\title{
Research of Risk Assessment in the Boiler Water Treatment System Based on Layers of Protection Analysis
}

\author{
Huiling Li \\ Institute of Chemical Machinery and Safety \\ Engineering \\ South China University of Technology \\ Guangzhou, China \\ bigboy901@126.com
}

\author{
Nan Jiang \\ Institute of Chemical Machinery and Safety \\ Engineering \\ South China University of Technology \\ Guangzhou, China \\ jnscut@126.com
}

\author{
Bo Deng \\ Institute of Foshan Inspection \\ Guangdong Special Equipment Inspection and Research \\ Institute \\ Foshan, China \\ 14935796@qq.com
}

\begin{abstract}
For the purpose of solving problems in water treatment system of the power station boiler from perspective of chemical process safety, a new method which uses the LOPA method in risk assessment for anticorrosion and scale inhibition properties of boiler system is proposed. First of all, a new annotation on the basic principle and calculation steps of LOPA is made in this paper. And then the consequence of the hazard scenario is determined by calculating the probability of accidents, such as putting poor quality water treated by the water treatment agents as initial event. Finally, specific implementable recommendations are provided by comparing the risk levels of independent protective layers system and ordinary system. The results show that the method that LOPA used in risk assessment for anticorrosion and scale inhibition properties of boiler is feasible, measures that recommended can reduce the risk; LOPA can further enrich HAZOP analysis results when introduced into boiler capacity link; layers of protection analysis, risk assessment together with humanistic management could be a new and effective security management model used by energy enterprise.
\end{abstract}

Key words: water treatment system; scaling and corrosion; layers of protection analysis (LOPA); safety countermeasures research; humanistic management

\section{INTRODUCTION}

The safety and operation of the boiler are seriously affected by the quality of boiler water. The scale and corrosion of boiler tubes, which directly affect the thermal efficiency and the strength of materials of the boiler, and shorten the boiler life and even cause the boiler leakage and explosion accident, are caused by the poor quality water. Theoretically, the boiler water treatment is to remove various impurities in water by physical and chemical methods, to prevent phenomena of scaling, corrosion and salt accumulation from spreading in boiler water vapor system, to ensure the steam quality, to prolong the safely working life of the boiler.

From the foregoing, the normal operation of boiler water treatment system is closely related to the treatment effect of each stage. Water treatment problems of later stages are widespread, such as: the ill effects for steam equipment caused by excessive amounts of steam sodium and silicon, high blowdown rate which increases 1 percent with the fuel consumption increasing 0.3 percent [1], the condensate corrosion of iron and copper equipment. In recent years, with the rapid development of new technology of water treatment it has effectively overcome the shortcomings of conventional technology, and has opened up a new, scientific and effective way for boiler effectively working on the state of anticorrosion, scale inhibition, energy conservation and environmental protection[2 $\sim 5]$.

Nowadays, as environmental factors are dynamic and diversified, industrial accidents that frequently happened bring serious losses of lives and property, yet negative and incalculable impact. Therefore, the research of risk process has received more attention. Throughout the domestic and external study of boiler water treatment, it mainly focused on the new methodologies and new processes, however, the research on risk assessment and security management of boiler water treatment has been reported few. Layers of protection analysis (LOPA) method was applied to the chemical plant by some scholars for reducing the risk of accidents [6,7], and it has proved to be effective. In this paper, LOPA method is introduced to the boiler water treatment system in power plant for assessing the adequacy of protection layers and the reasonability of process for evaluating the risk of corrosion and scale inhibition performance of boiler water treatment system from perspective of chemical process safety.

As major and serious production safety accidents repeatedly occur, "people's lives and safety" has been put 
on the new agenda. In hence, the "humanistic management" was recommended as another business idea of enterprise. The risk management model could be changed from the traditional method that based on experience into the process safety management with characters of systematic and people-oriented, which can effectively control and reduce boiler accidents, and improve the risk management level of enterprises.

\section{WHAT IS LAYERS OF PROTECTION ANALYSIS (LOPA)?}

Layers of protection analysis (LOPA) has been a powerful analytical tool for safety design and management used widely in the world since 2000[8]. LOPA builds upon well-known process hazards analysis techniques, applying objective and semi-quantitative measures to the evaluation of the frequency of potential incidents and the probability of failure of the protection layers. Layers of safeguards are set by enterprises for preventing the consequences of potentially hazardous events, which can be described with a graphic model of the "onion". The independent protection layer (IPL) should be considered as a safety protection measures to prevent accidents when LOPA is implemented on hazard scenarios according to the above model.

\section{NEW ANNOTATION OF LOPA}

The basic process and calculation method are annotated from a more scientific way. LOPA is typically applied after a qualitative hazards analysis has been completed which concluding the determination of hazard scenario and its consequence. The new risk matrix shown in Table 1 was drawn out on the basis of previous research work, which builds upon hazard and operability (HAZOP) and divides the risk into 4 levels calculated by 7 levels of the initiating cause frequencies and 5 categories of the hazard scenario consequences.

The main analysis steps of LOPA are summarized as shown in Table 1. Among them, the event probability and failure probability can be gained through statistical data and technical judgment [9].

TABLE I. THE MAIN STEPS OF LOPA

\begin{tabular}{|c|c|c|}
\hline \multicolumn{2}{|c|}{ Main steps } & Description \\
\hline $\begin{array}{l}\text { STEP } \\
1\end{array}$ & $\begin{array}{l}\text { Record all } \\
\text { design } \\
\text { documents and } \\
\text { reference } \\
\text { documentation }\end{array}$ & $\begin{array}{l}\text { Including process flow diagrams (PFDs), } \\
\text { piping and instrumentation diagrams (P\& } \\
\text { IDs), protection layer design documents } \\
\text { and inspection reports, etc. }\end{array}$ \\
\hline $\begin{array}{l}\text { STEP } \\
2\end{array}$ & $\begin{array}{l}\text { Document the } \\
\text { process } \\
\text { deviation and } \\
\text { hazard scenario }\end{array}$ & Obtained from HAZOP analysis \\
\hline $\begin{array}{l}\text { STEP } \\
3\end{array}$ & $\begin{array}{l}\text { Identify all of } \\
\text { the initiating } \\
\text { causes for the } \\
\text { process } \\
\text { deviation and } \\
\text { determine their } \\
\text { frequencies }\end{array}$ & $\begin{array}{l}\text { Calculate the frequency of unmitigated } \\
\text { event according to the frequency of each } \\
\text { initiating cause, and determine potential } \\
\text { risk level }\end{array}$ \\
\hline $\begin{array}{l}\text { STEP } \\
4\end{array}$ & $\begin{array}{l}\text { Determine the } \\
\text { consequence of }\end{array}$ & $\begin{array}{l}\text { including safety, environmental, } \\
\text { economic and society losses }\end{array}$ \\
\hline
\end{tabular}

\begin{tabular}{|c|c|c|}
\hline \multicolumn{2}{|c|}{ Main steps } & \multirow[t]{2}{*}{ Description } \\
\hline & $\begin{array}{l}\text { the hazard } \\
\text { scenario }\end{array}$ & \\
\hline $\begin{array}{l}\text { STEP } \\
5\end{array}$ & $\begin{array}{l}\text { Estimate the } \\
\text { risk of the } \\
\text { scenario by } \\
\text { combining the } \\
\text { consequence } \\
\text { frequency and } \\
\text { consequence } \\
\text { severity }\end{array}$ & $\begin{array}{l}\text { List the IPLs, calculate the frequency of } \\
\text { mitigated event by combining the } \\
\text { initiating event frequency and the IPL } \\
\text { probabilities }\end{array}$ \\
\hline $\begin{array}{l}\text { STEP } \\
6\end{array}$ & $\begin{array}{l}\text { Provide specific } \\
\text { implementable } \\
\text { recommendatio } \\
\text { ns }\end{array}$ & $\begin{array}{l}\text { Further safeguards are not required if } \\
\text { residual risk lowered to a tolerable level }\end{array}$ \\
\hline
\end{tabular}

In LOPA analysis, the risk of unmitigated event that leading to an accident without safeguards in consideration is called the potential risk, on the contrary, the risk of mitigated event that leading to an accident after implementing IPLs is called residual risk. Firstly, determine potential risk level of unmitigated event based on analysis of the event chain process and the probability of each initiating cause. Afterwards, estimate the risk level of mitigated event by combining the initiating event frequency and the IPL probabilities. According to related conclusions in literature and derivation [10], the frequency for unmitigated event and mitigated event can be estimated with the following equation:

$$
\begin{aligned}
& f_{C}=\prod_{i=1}^{3} f_{i} \\
& f_{R}=f_{C} \times \prod_{j=1}^{J} P F D_{j}
\end{aligned}
$$

where $f_{C}$ is the unmitigated event frequency, calculated by multiplying the initiating cause frequency, $f_{R}$ is the final mitigated event frequency, calculated by multiplying $f_{C}$ by the PFDs of the individual IPLs, $P F D_{j}$. The risk of the scenario is estimated by combining the consequence frequency and consequence severity, and corresponding recommendations are put forward from the LOPA team as shown in Table 2.

TABLE II. RISK LEVELS AND CORRESPONDING RECOMMENDATIONS

\begin{tabular}{|l|l|l|}
\hline \multicolumn{2}{|c|}{ Risk levels } & \multicolumn{2}{c|}{ Table Column Head } \\
\hline I & $1 \sim 5$ & No additional safeguards are required \\
\hline II & $6 \sim 8$ & $\begin{array}{l}\text { Non-coercive: safeguards should be taken when } \\
\text { its economic conditions permit }\end{array}$ \\
\hline III & $9 \sim 11$ & $\begin{array}{l}\text { Safeguards should be in plan, such as: } \\
\text { maintenance period of production equipment } \\
\text { and facilities }\end{array}$ \\
\hline IV & $12 \sim 13$ & Safeguards must be taken immediately \\
\hline
\end{tabular}




\section{CASE STUDY IN BOILER WATER TREATMENT SYSTEM}

The risk assessment is implemented based on the water treatment system of high pressure pulverized coal fired boiler used by a certain power plant. The boiler specification is set as a rated production of $220 \mathrm{t} / \mathrm{h}$ and a rated pressure of $9.81 \mathrm{MPa}$, and its water treatment process as follows: ammonia was added to boiler feedwater through the export of deaerator for adjusting $\mathrm{pH}$ value to 8.8 9.3, diammonium and phosphate trisodium were respectively and continuously added into drum through dosing pump for oxygen removal and water desalination. The whole device was composed of raw water filtration unit, water desalination unit, oxygen and boiler water dosing unit, etc.

\section{A. HAZOP analysis of boiler water treatment system}

During the HAZOP study, units of boiler water treatment process such as feedwater treatment system, water treatment system, feedwater and boiler-water dosing system were divided into several nodes, as shown in Table 3.

\begin{tabular}{|c|c|c|c|c|c|c|}
\hline TABL & & $\begin{array}{l}\text { AZOP ANALY } \\
\text { SYSTE }\end{array}$ & $\begin{array}{l}\text { RESULTS O } \\
\text { (PART) }\end{array}$ & VATE & REAT & \\
\hline \multirow[b]{2}{*}{$\begin{array}{c}\text { Deviati } \\
\text { on }\end{array}$} & \multirow[b]{2}{*}{$\begin{array}{c}\text { Caus } \\
\text { e }\end{array}$} & \multirow[b]{2}{*}{$\begin{array}{c}\text { Consequenc } \\
\mathbf{e}\end{array}$} & \multirow{2}{*}{$\begin{array}{c}\text { Existing } \\
\text { safeguard } \\
\mathrm{s}\end{array}$} & \multicolumn{3}{|c|}{ Unmitigated Risk } \\
\hline & & & & $\begin{array}{l}\text { Seve } \\
\text { rity }\end{array}$ & $\begin{array}{c}\text { Freq } \\
\text { uenc } \\
y\end{array}$ & $\begin{array}{c}\text { Lev } \\
e l\end{array}$ \\
\hline $\begin{array}{l}\text { Insuffic } \\
\text { ient } \\
\text { oxygen } \\
\text { remova } \\
1\end{array}$ & $\begin{array}{l}\text { Over } \\
\text { much } \\
\text { dissol } \\
\text { ved } \\
\text { oxyge } \\
\mathrm{n} \text { in } \\
\text { feedw } \\
\text { ater }\end{array}$ & $\begin{array}{l}\text { oxygen } \\
\text { corrosion } \\
\text { and surface } \\
\text { pit occurred } \\
\text { on pipeline } \\
\text { inwall }\end{array}$ & $\begin{array}{l}\text { Diammon } \\
\text { ium as } \\
\text { oxygen } \\
\text { removal }\end{array}$ & 2 & 7 & 8 \\
\hline $\begin{array}{l}\text { Insuffic } \\
\text { ient } \\
\text { water } \\
\text { desalin } \\
\text { ation }\end{array}$ & $\begin{array}{l}\text { Contr } \\
\text { ol of } \\
\text { the } \\
\text { water } \\
\text { qualit } \\
\text { y } \\
\text { indica } \\
\text { tors } \\
\text { not } \\
\text { strictl } \\
\text { y }\end{array}$ & $\begin{array}{l}\text { Serious } \\
\text { entrainment, } \\
\text { the steam } \\
\text { quality } \\
\text { affected, } \\
\text { higher } \\
\text { blowdown } \\
\text { and energy } \\
\text { consumption }\end{array}$ & $\begin{array}{l}\text { phosphate } \\
\text { trisodium } \\
\text { as water } \\
\text { desalinati } \\
\text { on }\end{array}$ & 3 & 7 & 9 \\
\hline $\begin{array}{l}\text { Poor } \\
\text { water }\end{array}$ & $\begin{array}{l}\text { Scale } \\
\text { group } \\
\mathrm{PO}_{4}{ }^{3-} \\
\text { and } \\
\text { corros } \\
\text { ive } \\
\text { ions } \\
\mathrm{Fe}^{3+}\end{array}$ & $\begin{array}{l}\text { Poor steam } \\
\text { quality, scale } \\
\text { and } \\
\text { corrosion of } \\
\text { boiler tubes }\end{array}$ & $\begin{array}{l}\text { Conventio } \\
\text { nal water } \\
\text { treatment } \\
\text { agent }\end{array}$ & 3 & 5 & 7 \\
\hline
\end{tabular}

\section{B. LOPA analysis of boiler water treatment system}

After factory data investigation and discussion meeting, risk management team made the following decision: the original water treatment agent replaced by new-type boiler water treatment agent of EWPT-6207/6351, routine monitoring of water quality implemented in the period of boiler operation, condition based maintenance supplied for equipment. If the level 1 layer boiler water treatment agent failed, corrosion and scale would occur on pipelines and cause lower compression strength and higher fluid resistance, which leading to occurrence of boiler pipe explosion. That is why routine monitoring and condition based maintenance were used as level 2 and level 3 by risk management team after cautious consideration.

Benefiting from the EWPT agent, negative effect of the original drug has been avoided, feedwater $\mathrm{pH}$ value has been steadily controlled, dissolved oxygen, sodium, silicon and other indicators have been resticted within the prescribed scope, and good quality of boiler water has been ensured. According to the statistical data and technical judgment [11], EWPT agent PFD is 0.02, and the PFD in both routine monitoring and condition based maintenance is 0.1 .

The information of initiating causes, consequence and safeguards can be shown in Table $\mathbf{3}$, but the following information can not be found: risk level of the hazard scenario, availability of safeguards. In this paper, layer of protection analysis of poor water scenario in boiler water treatment system was developed as shown in Table 4.

TABLE IV. LOPA ANALYSIS RESULTS OF BOILER WATER TREATMENT SYSTEM (PART)

\begin{tabular}{|c|c|c|c|c|c|c|c|}
\hline $\begin{array}{c}\text { Haza } \\
\text { rd } \\
\text { scena } \\
\text { rio }\end{array}$ & $\begin{array}{c}\text { Con } \\
\text { sequ } \\
\text { ence } \\
\& \\
\text { seve } \\
\text { rity }\end{array}$ & $\begin{array}{c}\text { Initiati } \\
\text { ng } \\
\text { cause } \\
\& \\
\text { frequen } \\
\text { cy }\end{array}$ & $\begin{array}{c}\text { Unmi } \\
\text { tigate } \\
\text { d } \\
\text { event } \\
f_{C} \\
f_{C} \\
\left(\begin{array}{c}\text { year } \\
\left.{ }^{-1}\right)\end{array}\right.\end{array}$ & $\begin{array}{c}\text { IPLs } \\
\text { and } \\
\text { PFD } \\
\text { value } \\
\text { s }\end{array}$ & $\begin{array}{c}\begin{array}{c}\text { Mitig } \\
\text { ated } \\
\text { event }\end{array} \\
f_{R} \\
f_{(\text {year }} \\
\left.{ }_{-1}\right)\end{array}$ & $\begin{array}{c}\text { Meet } \\
\text { criter } \\
\text { ion } \\
\left(10^{-}\right. \\
5 / \text { yea } \\
\text { r) }\end{array}$ & $\begin{array}{c}\text { Reco } \\
\text { mme } \\
\text { ndati } \\
\text { ons }\end{array}$ \\
\hline $\begin{array}{l}\text { Corro } \\
\text { sion } \\
\text { and } \\
\text { scale } \\
\text { cause } \\
\text { d by } \\
\text { poor } \\
\text { water, } \\
\text { resulti } \\
\text { ng } \\
\text { into } \\
\text { pipe } \\
\text { ruptur } \\
\text { e }\end{array}$ & $\begin{array}{l}\text { Seri } \\
\text { ous } \\
\text { corr } \\
\text { osio } \\
\mathrm{n} \\
\text { and } \\
\text { scale } \\
\text { to } \\
\text { resul } \\
\mathrm{t} \text { in } \\
\text { pipe } \\
\text { expl } \\
\text { osio } \\
\mathrm{n} \text {. } \\
\text { Blast } \\
\text { wav } \\
\text { es } \\
\text { may } \\
\text { caus } \\
\mathrm{e} \\
\text { fatali } \\
\text { ties } \\
\text { and } \\
\text { prop } \\
\text { erty } \\
\text { losse } \\
\mathrm{s} \text {. } \\
\text { Leve } \\
\mathbf{1 3}\end{array}$ & $\begin{array}{l}\text { Failure } \\
\text { of the } \\
\text { original } \\
\text { agent, } \\
2.00 \times 10 \\
-1 / \text { year } \\
\text { 1.Corro } \\
\text { sion } \\
\text { and } \\
\text { scale in } \\
\text { boiler, } \\
1.00 / y e \\
\text { ar } \\
2 . \text { Lowe } \\
\text { r steam } \\
\text { quality, } \\
1.00 / y e \\
\text { ar } \\
1 . \text { Pipe } \\
\text { rupture } \\
\text { and } \\
\text { blast, } \\
1 \times 10- \\
2 / y e a r \\
2 . \text { Casua } \\
\text { tties, } \\
1.00 / y e \\
\text { ar }\end{array}$ & $\begin{array}{l}\text { Unmi } \\
\text { tiga } \\
\text { ted } \\
\text { risk } \\
\text { Level } \\
7\end{array}$ & $\begin{array}{l}\text { 1.EW } \\
\text { PT- } \\
6207 / \\
6351: \\
\text { PFD= } \\
2.00 \times \\
10- \\
2 \\
2 . \\
\text { routin } \\
\text { e } \\
\text { monit } \\
\text { oring: } \\
\text { PFD= } \\
1.00 \times \\
10^{-1}\end{array}$ & $\begin{array}{l}\text { Frequ } \\
\text { ency } \\
\text { Level } \\
2\end{array}$ & Yes & $\begin{array}{l}\text { No } \\
\text { additi } \\
\text { onal } \\
\text { safeg } \\
\text { uards } \\
\text { are } \\
\text { requir } \\
\text { ed }\end{array}$ \\
\hline
\end{tabular}

Table 4 shows a summary of the initiation events and independent layers of protection information. Unmitigated event frequency, $2.00 \times 10^{-3} /$ year, can be compared to the tolerability criterion of the tolerability criterion of less than $10^{-5}$ /year. Based on this comparison, other safeguards are required. After implementing three layers of protection of new-type boiler water treatment agent of EWPT$6207 / 6351$, routine monitoring of water quality and 
condition based maintenance, frequency of the hazard scenario reduces to $2.00 \times 10^{-6} /$ year from $2.00 \times 10^{-3} /$ year, and risk level reduces to fourth from seventh. For the risk determination, the estimated posterior risk value is below the tolerability criterion of less than $10^{-5} /$ year. Consequently, it is proved that the LOPA application can enrich HAZOP study and provide specific implementable recommendations.

\section{SAFETY MEASURES AND RECOMMENDATIONS}

\section{A. Recommendations on process and maintenance technology}

For the LOPA method placing emphasis on the process hazards analysis, it can reveal hidden dangers of the boiler which previous methods of qualitative analysis not covered, and provide more accurate information of maintenance for the enterprise. The whole process must be implemented around plan, and the information of design, operation and testing should be under control. Specific implementable recommendations are provided as follows. First, control the formation of scale by choosing economic and reasonable water treatment technology and conscientiously implementing routine monitoring of water quality, to ensure the $\mathrm{pH}$ value is controlled in the range of 7.0 9.6[12]. Take measures and report immediately if water shortage or water loss occurred in boiler system. Secondly, find out corrosion thin spot of the system and take measures to improve the ability of corrosion resistance. Provide implementable recommendations according to the problems and the characteristics of the boiler system, such as: the control of sulfur content in coal for coal-fired boiler is important. Thirdly, condition based maintenance can be a new direction. Determine maintenance content and time after prospect forecast on the high-risk equipment, to disassemble less the equipment and prolong its service life.

\section{B. Recommendations on humanistic management}

Human life is the most precious, the development must not be based on the sacrifice of human life, and this must be an impassable red line [13]. Look from the surface, boiler safety accidents are caused by the production space, facilities and other factors, but after a deeper analysis, the root of the problem is virtually the flaws and vulnerabilities of management. As the unsafe human behavior is the main reason for the boiler accident, the humanistic management model will be a big trend [14]. risk management team can combine the theory of five functions proposed by Henri Fayol [15] with the LOPA analysis results, to check boiler production safety. Collectively, safety production experience from different professionals can contribute to boiler safety modification.

\section{CONCLUSIONS}

Boiler water treatment study has focused on the exploration of new technology, but risk analysis involving both outcome frequency and consequence severity in this area has not been involved yet. In this paper, the
LOPA method is applied in the risk assessment on the boiler water treatment system, and the study is developed from the perspective of overall system and process. To summarize the clear and reasonable basic program and calculation formula of LOPA method, a theoretical reference of prevention and risk assessment for boiler major safety accident is provided. Then HAZOP problems of boiler water treatment system are summarized and combed from the perspective of system safety, layers of protection analysis, a new security operating model that combining risk assessment with humanistic management is put forward, providing technical reference and a new monitoring method for safety production of related enterprises.

\section{REFERENCES}

[1] WANG Zhong-xian,SHEN Hong-xin, New-type water treatment technology and and its application for industry boiler[J], Journal of Chemical Engineering \& Equipment, 2011, (8): 150-153.

[2] LIANG Hua-jie,SU Wei, FU Qiang. Reverse osmosis technology in engineering application of ultra supercritical once-through boiler make-up water treatment $[\mathrm{J}]$, Journal of Electric Power, ,2012,01:25-28.

[3] HE Jian-kang,ZHENG Cai-ping. application of Integrated membrane water treatment technology in boiler make-up water treatment system of Shaoguan Power Plant[J]. Thermal Power Generation,2013,07:142-143+146.

[4] Malaeb, L., Ayoub, G. M. Reverse osmosis technology for water treatment: state of the art review[J]. Desalination, 2011, (267): 1-8

[5] LI Lin-lin, SHAN Xue-min, GAO Li. Research on the Application of Ultra Filtration Technology to Water Treatment[J]. Safety and Environmental Engineering,2010,06:5-8.

[6] Yun, G. W., Rogers, W. J., Mannan, M. S. Risk assessment of LNG importation terminals using the Bayesian-LOPA methodology $[\mathrm{J}]$. Journal of Loss Prevention in the Process Industries, 2009, 22(1): 91-96

[7] WEI Hua. The Application Practice of LOPA in the $600 \mathrm{kt} / \mathrm{a}$ Methanol Project[J]. Automation in Petro-Chemical Industry, 2008, (6): 24-26

[8] Summers A E. Introduction to layers of protection analysis[J]. Journal of Hazardous Materials, 2003, 104(1): 163-168.

[9] ZHANG Qi-li, QIU Tong, ZHAO Jing-song, WANG Zhao-hui. Integrated Research of Three Kinds of Safety Evaluation Method[J]. Computers and Applied Chemistry, 2009, 26(8): 961965

[10] ZHOU Rong-yi, LI Shi-lin, LIU He-qing. Study on Application of LOPA in HAZOP[J]. China Safety Science Journal, 2010, 20(7): 76-81

[11] Center for Chemical Process Safety. Layer of Protection Analysis: Simplified Process Risk Assessment[M]. New York: Wiley, 2001: 60-80

[12] China Electricity Council.GB/T 12145-2008 Water Vapor Quality of Thermal Power Unit and Steam Power Equipment[S] Beijing: China Standards Press, 2008.

[13] XI Jin-ping. Always give top priority to people's life safety and to preventing major safety production accident[N]. People's Daily, 2013-06-08(1)

[14] HUANG Dan-hua. Humanistic Management is the Megatrends of Modern Enterprise Management[J]. Journal of Sichuan Normal University (Philosophy and Social Sciences), 1997, (2):46-48, 79

[15] H. Fayol. Administration Industrielle et Generale[M] . Beijing China Machine Press, 2007. 